RAD Conference Proceedings, vol. 2, pp. 95-98, 2017

www.rad-proceedings.org

novororitft

\title{
QUALITY CONTROL IN DENTAL RADIOLOGY IN SERBIA: PRELIMINARY RESULTS
}

\author{
Zoran Mirkov* \\ Serbian Institute of Occupational Health "Dr Dragomir Karajović”, Belgrade, Serbia
}

\begin{abstract}
For the purposes of this study, the quality control was carried out on 40 intraoral and 20 panoramic dental x-ray units in use in the public and private sector in Serbia. Parts of the quality control which are derived were: visual inspection of the dental $x$-ray units and related equipment, performance testing of the dental $x$-ray units and inspection of the radiation protection facilities for patient, personnel and population. Results show that most of the examined devices (88\% intraoral and $95 \%$ panoramic $x$-ray units) operate within regulatory standards. The worst results showed intraoral devices that operate on $50 \mathrm{kV}$ within the repeatability of exposure time and the lack of adequate filtration. The main reason for this is the irregular and insufficient servicing of $x$-ray units and related equipment.
\end{abstract}

Key words: Dental radiology, quality control

DOI: $10.21175 /$ RadProc.2017.20

\section{INTRODUCTION}

The number of examinations in diagnostic radiology, which is the largest contributor to the population dose from man-made sources of ionising radiation, is steadily increasing. According to the United Nations Scientific Committee on the Effects of Atomic Radiation (UNSCEAR) report from 2008, 3.6 billion radiological examinations were executed each year in the world, of which 480 million examinations were from dental radiology [1]. The contribution of dental x-ray units to all $x$-ray units in our country is larger than 25\% [2]. This is one of the reasons why it is very important to perform regular quality control (QC) in this branch of diagnostic radiology: this is performed (on annual basis or after servicing of the x-ray unit) according to national legislative [3], and QC protocols that have been adopted from international standards and guidelines [4, 5], which have been modified according our practice and measuring equipment [6].

It is worth mentioning that there is still a significant number of single-phase generator $x$-ray units (average age $\geq 25$ years), mainly in the public sector, but the situation has been improving in the past few years. There is, also, an increasing number of the Cone Beam Computed Tomography (CBCT) x-ray units and significant steps have been made to establish a protocol of quality control according to European Commission Radiation Protection Publication $\mathrm{N}^{\circ} 172$ [7].

The aim of this study, based on the measured sample was to present the state of X-ray units, in relation to the equipment and facilities for radiation protection for patients, staff and the population in dental diagnostic radiology in the country and to indentify guidelines for improving the overall quality in the case of practice and radiological protection.

\section{Materials AND METHODS}

Results for this study were obtained during the regular annual quality control inspection performed in the year of 2016. The quality control was carried out on 40 intraoral and 20 panoramic dental x-ray units in use in the public and private sector in Serbia, as already stated, on the basis of national legislative [3] and international standards and guidelines $[4,5]$. Parts of the quality control which are derived were given in Table 1, 2 and 3. Criteria for performance testing of the dental x-ray units and visual inspection of the dental $\mathrm{x}^{-}$ ray units and related equipment were taken from national legislative $[3,8]$.

Table 1. Visual inspection of the dental x-ray units and related equipment

\begin{tabular}{|l|l|}
\hline Parameter & Criterion \\
\hline Mechanical stability & Pass/No pass \\
\hline Focus to skin distance (FSD) & \\
Intraoral & $\geq 10 \mathrm{~cm}$ \\
Panoramic & $\geq 15 \mathrm{~cm}$ \\
\hline Operating tube potential & $\geq 50 \mathrm{kV}$ \\
\hline State of image receptor & Pass/No pass \\
\hline
\end{tabular}

Table 2. Inspection of the radiation protection facilities for patient, personnel and population

\begin{tabular}{|l|l|}
\hline Parameter & Criterion \\
\hline $\begin{array}{l}\text { The adequacy of structural } \\
\text { protection }\end{array}$ & $\begin{array}{l}\text { Satisfactory/Not } \\
\text { satisfactory }\end{array}$ \\
\hline Protective equipment & $\begin{array}{l}\text { Satisfactory/Not } \\
\text { satisfactory }\end{array}$ \\
\hline Personal dosimeters & Yes/No \\
\hline
\end{tabular}

*zoran.mirkov@institutkarajovic.rs 
Additional information that is required from the dental staff in the facility, during the annual quality control is whether the devices and associated equipment are regularly serviced.

All measurements in the case of performance testing of dental x-ray devices were performed by a regularly calibrated multimeter MPD Barracuda (RTI Electronics AB, Sweden).

Table 3. Performance testing of the dental x-ray units

\begin{tabular}{|l|l|}
\hline Parameter & Criterion \\
\hline Intraoral & $< \pm 10 \%$ \\
\hline kVp reproducibility & $< \pm 10 \%$ \\
\hline Timer accuracy & $< \pm 10 \%$ \\
\hline Timer reproducibility & $< \pm 10 \%$ \\
\hline Tube output reproducibility at FSD & \\
\hline Half - value layer (HVL) & $\geq 1.5 \mathrm{mmAl}$ \\
For voltage $<70 \mathrm{kV}$ & $\geq 2.5 \mathrm{mmAl}$ \\
For voltage $>70 \mathrm{kV}$ & \\
\hline Panoramic & $< \pm 10 \%$ \\
\hline kVp reproducibility & $< \pm 10 \%$ \\
\hline Timer accuracy & $< \pm 10 \%$ \\
\hline Timer reproducibility & \\
\hline Half - value layer (HVL) & $\geq 1.5 \mathrm{mmAl}$ \\
For voltage $<70 \mathrm{kV}$ & $\geq 2.5 \mathrm{mmAl}$ \\
For voltage $>70 \mathrm{kV}$ & $< \pm 10 \%$ \\
\hline Tube output reproducibility & \\
\hline
\end{tabular}

Table 4. List of examined intraoral dental x-ray devices and their basic technical characteristics

\begin{tabular}{|c|c|c|c|c|}
\hline X-ray unit & $\begin{array}{c}\text { Nominal } \\
\text { X-ray } \\
\text { tube } \\
\text { voltage } \\
(\mathrm{kV})\end{array}$ & $\begin{array}{l}\text { X-ray } \\
\text { tube } \\
\text { current } \\
(\mathrm{mA})\end{array}$ & 总. & $\begin{array}{c}\text { Total } \\
\text { filtration } \\
(\mathrm{mm} \mathrm{Al})\end{array}$ \\
\hline Dent (Ei Niš) & 50 & 10 & 12 & 1.5 \\
\hline $\begin{array}{c}\text { CS 2100 } \\
\text { (Carestream) }\end{array}$ & 60 & 7 & 4 & 2 \\
\hline $\begin{array}{c}\text { Intra } \\
\text { (Planmeca) }\end{array}$ & 70 & 8 & 4 & 2 \\
\hline $\begin{array}{c}\text { Heliodent } \\
\text { Vario } \\
\text { (Sirona) }\end{array}$ & 70 & 7 & 9 & 1.5 \\
\hline $\begin{array}{l}\text { Expert DC } \\
\text { (Gendex) }\end{array}$ & 65 & 7 & 4 & 1.5 \\
\hline Gnatus & 70 & 7 & 2 & 3.22 \\
\hline $\begin{array}{c}\text { Elitys } \\
\text { (Trophy) }\end{array}$ & 70 & 8 & 2 & 2.5 \\
\hline $\begin{array}{c}\text { Minray } \\
\text { (Soredex) }\end{array}$ & 70 & 7 & 3 & 2 \\
\hline
\end{tabular}

Table 5. List of examined panoramic dental x-ray devices and their basic technical characteristics

\begin{tabular}{|c|c|c|c|c|}
\hline $\mathrm{X}$-ray unit & $\begin{array}{c}\text { Nominal } \\
\text { X-ray } \\
\text { tube } \\
\text { voltage } \\
(\mathrm{kV})\end{array}$ & $\begin{array}{l}\text { X-ray } \\
\text { tube } \\
\text { current } \\
(\mathrm{mA})\end{array}$ & 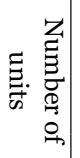 & $\begin{array}{c}\text { Total } \\
\text { filtration } \\
(\mathrm{mm} \mathrm{Al})\end{array}$ \\
\hline $\begin{array}{c}\text { Pax I } \\
\text { (Vatech) }\end{array}$ & $50-90$ & $4-10$ & 3 & $\geq 2.5$ \\
\hline $\begin{array}{c}\text { Cranex } \\
\text { (Soredex) }\end{array}$ & $63-81$ & $6-10$ & 8 & $\geq 2.5$ \\
\hline Planmeca & 70 & 8 & 2 & $\geq 2.5$ \\
\hline $\begin{array}{l}\text { Orthopanto } \\
\text { mograph } \\
\text { (Siemens) }\end{array}$ & 75 & 10 & 4 & $\geq 2.5$ \\
\hline $\begin{array}{c}\text { GX DP-30o } \\
\text { (Gendex) }\end{array}$ & $66-77$ & 10 & 3 & $\geq 2.5$ \\
\hline
\end{tabular}

In order to check the stability of the devices, all the measurements were repeated 5 times and the results were statistically analyzed (mean, standard deviation, minimum and maximum values). Measured quantities along with the criterion for permitted limit values are given in Table 3.

Measurements of the ambient dose equivalent rate for the inspection of the adequacy of structural protection (Table 2) were performed by regularly calibrated Ion Chamber Survey Meter Victoreen 451P (Fluke Biomedical, U.S.A.).

The list and number of examined intraoral and panoramic dental $\mathrm{x}$-ray devices with their basic technical characteristics are shown in Table 4 and 5 .

\section{RESULTS AND DISCUSSION}

Results of the visual inspection of dental x-ray units and related equipment shows that, among 60 inspected devices, 5 has a poor mechanical stability, 2 have inadequate focus to skin distance (FSD) (dimensions of $\mathrm{x}$-ray collimator $<10 \mathrm{~cm}$ ). Two other parameters, in the case of visual inspection, operating tube voltage and the state of the image receptors, were found to have pass criteria for all inspected devices.

Table 6. The measurement results of performance testing of the intraoral dental $\mathrm{x}$-ray units

\begin{tabular}{|l|c|c|c|c|}
\hline & Mean & $\begin{array}{c}\text { Standard } \\
\text { deviation }\end{array}$ & Min & Max \\
\hline $\begin{array}{l}\text { kVp reproducibility } \\
\text { \%) }\end{array}$ & -3.2 & 5.0 & -14.0 & 5.2 \\
\hline Timer accuracy (\%) & -0.5 & 5.9 & -10.0 & 25.0 \\
\hline Timer & -1.8 & 4.9 & -9.8 & 20.1 \\
reproducibility (\%) & \multicolumn{5}{|l}{} \\
\hline HVL (mmAl) & 1.55 & 0.34 & 0.9 & 2.24 \\
\hline $50 \mathrm{kVp}$ & 1.8 & 0.1 & 1.7 & 2.0 \\
$60 \mathrm{kVp}$ & 1.7 & 0.1 & 1.6 & 1.9 \\
$65 \mathrm{kVp}$ & 1.9 & 0.3 & 1.6 & 2.5 \\
$70 \mathrm{kVp}$ & 0.2 & 0.7 & 0.2 & 1.0 \\
\hline Radiation output reproducibility \% & 0.4 \\
\hline $50 \mathrm{kVp}$ & 0.4 & 0.4 & 0.2 & 0.8 \\
$60 \mathrm{kVp}$ & 1.0 & 0.1 & 1.0 & 1.2 \\
$65 \mathrm{kVp}$ & 0.9 & 0.4 & 0.4 & 1.8 \\
$70 \mathrm{kVp}$ & \multicolumn{5}{|l}{} \\
\hline
\end{tabular}

Table 7. The measurement results of performance testing of the panoramic dental $\mathrm{x}$-ray units

\begin{tabular}{|l|c|c|c|c|}
\hline \multicolumn{1}{|c|}{ Parameter } & Mean & $\begin{array}{c}\text { Standard } \\
\text { deviation }\end{array}$ & Min & Max \\
\hline $\begin{array}{l}\text { kVp reproducibility } \\
\text { (\%) }\end{array}$ & 0.5 & 4.6 & -7.8 & 9.9 \\
\hline $\begin{array}{l}\text { Timer } \\
\text { reproducibility (\%) }\end{array}$ & -0.1 & 2.0 & -5.1 & 4.8 \\
\hline HVL (mmAl) & 2.8 & 0.7 & 2.1 & 3.8 \\
\hline $66 \mathrm{kVp}$ & 2.8 & 0.1 & 2.7 & 2.8 \\
\hline $70 \mathrm{kVp}$ & 2.7 & 1.7 & 0.2 & 4.9 \\
\hline $75 \mathrm{kVp}$ & 2.8 & 0 & 2.8 & 2.8 \\
\hline $80 \mathrm{kVp}$ & 4.8 & 7.0 & 0.3 & 16.7 \\
\hline $\begin{array}{l}\text { Radiation output reproducibility } \\
\text { Coefficient of variation (\%) }\end{array}$ & 7.3 & 5.2 & 0.3 & 16.1 \\
\hline $66 \mathrm{kVp}$ & 12.7 & 8.8 & 0.7 & 24.0 \\
\hline $70 \mathrm{kVp}$ & 0.4 & 0 & 0.4 & 0.4 \\
\hline $75 \mathrm{kVp}$
\end{tabular}

Results of the inspection of the radiation protection facilities for the patients, personnel and population 
show that the adequacy of structural protection was satisfactory in all inspected cases; the measured results of the ambient equivalent dose rate do not exceed onethird of the limit values for personnel and public, respectively [8]. In two cases the protective equipment for patient was found to be unsatisfactory and, in two facilities, the personnel were not wearing personal dosimeters.

Measurements of the performance testing of intraoral and panoramic dental x-ray units were carried out after the removal of all existing defects that were observed during the inspection of devices and radiation protection of facilities. The final results are presented in Table 6 and 7 , showing the mean, standard deviation and minimum and maximum values. The tube operating potential value affects the value of the radiation output and half-value layer (HVL), and, therefore, is given separately for each value individually [9].

The interview with the staff showed that, in $70 \%$ of inspected facilities, the regular service to $\mathrm{X}$-ray devices and related equipment was not performed.

Among the examined intraoral and panoramic Xray units, there were a number of models and manufacturers [9]. Differences exist in the case of image receptors. The ratio between the film and digital sensors as the receptors were $60 \%$ to $40 \%$.

A third of the reviewed units were older than 20 years, and almost a half was installed in the last two years. Most of the examined devices (88\% of intraoral and $95 \%$ of panoramic x-ray units) operate within the regulatory standards. The performance test of intraoral dental $x$-ray units showed that $95 \%$ of the units met the standards related to the $\mathrm{kVp}$ reproducibility, $90 \%$ of them met HVL standards, and $2.5 \%$ did not have the sufficient time accuracy and repeatability. As far as the performance of panoramic dental X-ray units is concerned, $95 \%$ of the units met the standards for $\mathrm{kVp}$ reproducibility, time accuracy and repeatability, while $5 \%$ did not have adequate HVL. Of 5 intraoral X-ray machines whose measurements were out of the standard framework, 4 devices had mono-pulse generators and an age of over 25 years.

\section{CONClusion}

From this sample of examined X-ray units, related equipment, and requirements concerning radiological protection, it can be concluded that there is plenty of room for improvement. For the start, replacing older devices (tube operating potential $-50 \mathrm{kVp}$, length of $\mathrm{x}-$ ray collimator $-10 \mathrm{~cm}$, exposure time $\geq 0.8 \mathrm{~s}$ ) with newer (tube operating potential $\geq 60 \mathrm{kVp}$, length of $\mathrm{x}-$ ray collimator $\geq 20 \mathrm{~cm}$, exposure time $\leq 0.25 \mathrm{~s}$ ) will significantly contribute to reduce dose to patients.

To make quality control results more complete, the regular annual check should include measurements relating to the dose for patients, checking the image quality and the number of repeated images. Data on patient doses in intraoral dental radiology already exist in the context of the preliminary results $[10,11]$, which should be extended to a larger sample, and they need to join the data on doses to patients in the event of exposure with a panoramic X-ray devices.
Finally, it should be noted that a more regular service of X-ray devices and accessories should also significantly improve the overall situation in dental radiology. A more regular service with regular quality control is likely to improve the quality of practice and radiological protection and, therefore, lower doses for patients.

\section{REFERENCES}

1. "UNSCEAR 2008 Report: Sources and effects of ionizing radiation," UNSCR, New York (NY), USA, Rep. 2008 (vol. 1), 2008.

Retrieved from:

http://www.unscear.org/docs/publications/2008/UNS CEAR 2008 Report Vol.I.pdf

Retrieved on: Nov. 22, 2016

2. D. Košutić, P. Božović, "Rendgen aparati u dijagnostičkoj radiologiji na teritoriji Srbije u 2012. Godini," u Zbornik radova, XXVII Simpozijum DZZ SCG, Vrnjačka Banja, Srbija, 2013, str. 197-199. (D. Košutić, P. Božović, "Distribution of x ray units in Serbia," in Proc. XXVII Symposium DZZ SCG, Vrnjačka Banja, Serbia, 2013, pp. 197-200.)

Retrieved from:

http://dzz.org.rs/wp-content/uploads/2013/06/2013Vrnjacka-Banja.pdf

Retrieved on: Jan. 20, 2017

3. Правилник о примени извора јонизујућих зрачења y медицини, Сл. Гл. РС (бр. $1 / 12$ од 11.01.2012), Београд, Србија, 2012. (Rulebook on Application of the Radiation Sources in Medicine, Off. Gazett. RS (no. 1/12 from Jan. 11, 2012), Belgrade, Serbia, 2012.). Retrieved from:

http://www.srbatom.gov.rs/srbatom/zakonskaregulativa.htm

Retrieved on: Dec. 5, 2016

4. Vrednovanje $i$ redovna ispitivanja $u$ medicinskim odeljenjima za vizuelizaciju slike - Deo 3-4: Prijemna ispitivanja - Performanse vizuelizacije slike stomatoloških rendgen-aparata, SRPS IEC 61223-3-4:2002, 26.09.2002. (Evaluation and routine tests in medical imaging departments - Part 3-4: Acceptance tests - Imaging performance of dental $X$ ray equipment, SRPS IEC 61223-3-4:2002, Sep. 26, 2002.)

5. A. L. C. Kwan, H. Ching et al., "Acceptance Testing and Quality Control of Dental Imaging Equipment," American Associations of Physics in Medicine, Alexandria (VA), USA, Rep. 175, 2016.

Retrieved from:

http://www.aapm.org/pubs/reports/RPT 175.pdf

Retrieved on: Jan. 15, 2016

6. C. Olivera, D. Kosutic, S. Markovic, "Quality control of conventional diagnostic radiology equipment in Serbia and Montenegro," in Proc. IRPA Reg. Cong. Rad. Prot. Centr. Eur., Bratislava, Slovakia, 2003, p. VIII._2

Retrieved from:

http://www.iaea.org/inis/collection/NCLCollectionStor e/ Public/36/097/36097664.pdf?r=1

Retrieved on: Jan. 20, 2017

7. "Cone beam CT for dental and maxillofacial radiology (Evidence-Based Guidelines)," Directorate-General for energy of EC, Luxemburg City, Luxemburg, Rep. 172, 2012.

Retrieved from:

https://ec.europa.eu/energy/sites/ener/files/document s/172.pdf

Retrieved on: Jan. 20, 2017

8. Правилник о границама излагања јонизујућим зрачењима и мерењима ради процене нивоа излагања јонизујућим зрачењима, Сл. гл. РС (бр. 86/11 од 18.11.2011), Београд, Србија, 2011. 
(Rulebook on Limits of Exposure to Ionizing Radiation and Measurements for Assessment of the Exposure Levels, Off. Gazett. RS (no. 86/11 from Nov. 18, 2011), Belgrade, Serbia, 2011.)

Retrieved from:

http://www.srbatom.gov.rs/srbatom/zakonska-

regulativa.htm

Retrieved on: Jan. 20, 2017

9. K. Hatziioannou, E. Psarouli et al., "Quality control and diagnostic reference levels in intraoral dental radiographic facilities," Dentomaxillofacial Radiology, vol. 34, no. 5, pp. 304-307, Sep. 2005.

DOI: $10.1259 / \mathrm{dmfr} / 38802780$ PMid: 16120881

10. D. Arandjić, D. Košutić, Đ. Lazarević, "Patient Protection in Dental Radiology: Influence of Exposure
Time on Patient Dose," Serbian Journal of Electr. Eng., vol. 6, no. 3, pp. 489-494, Dec. 2009.

DOI: 10.2298/SJEE0903489A

11. Z. Mirkov, O. Ciraj, "Preliminarna ispitivanja nivoa doze za pacijente u intraoralnoj stomatološkoj radiologiji u Republici Srbiji," u Zbornik radova, XXVIII Simpozijum DZZ SCG, Vršac, Srbija, 2015, str. 301 - 306. (Z. Mirkov, O. Ciraj, "Preliminary testing the level of patient doses of intraoral dental radiology in Serbia," in Proc. XXVIII Symposium DZZ $S C G$, Vršac, Serbia, 2015, pp. 301 - 306.)

Retrieved from:

http://dzz.org.rs/wp-content/uploads/2013/06/2015-

XXVIII-DZZSCG-Vrsac.pdf

Retrieved on: Jan. 20, 2017 